\title{
Pemanfaatan IoT (Internet Of Things) Untuk Praktikum IPA Pada Materi Gerak Lurus Berubah Beraturan (GLBB) Dalam Pembelajaran Daring Selama Pandemi Covid-19
}

\author{
Fathurrahmaniah $^{1}$, Widia $^{2 *}$, Muarif Islamiah ${ }^{3}$, Fitria Sarnita ${ }^{4}$ \\ STKIP Harapan Bima123 \\ STKIP Taman Siswa Bima4 \\ Email : widia.fisika09@gmail.com
}

\begin{abstract}
Title (Utilization Of Iot (Internet Of Things) For Science Practices In Conditional Straight Motion Materials (GLBB) In Online Learning During The Covid-19 Pandemic). Science subjects, in several chapters of lessons that require practicum. The application of science has been widely developed as a demonstration tool when explaining abstract science concepts. Basically, science is learning that underlies all experimental activities. Science tools that can be used as learning media are used as practicum tools or demonstration props for science material, instrumentation in universities and science material on straight motion at school. The novelty in this research is the Development of Internet-based Science Practicum Tool Of Thigs. So as to be able to develop students' interest in learning science in the midst of the covid-19 pandemic. The novelty in this research is the Development of Internet-based Science Practicum Tool Of Thigs. So as to be able to provide an alternative for online science subject practicum in the midst of the covid-19 pandemic. This research uses the R \& $\mathrm{D}$ (Research And Development) method. The model used in this study is the ADDIE model. Meanwhile, the analysis of the implementation of the lesson plans during the learning process was 3.706 with a very good category. From the observations of 2 observers that the use of IoT is very helpful for students in understanding the concept of GLB in the midst of covid 19. This shows that in addition to improving student learning achievement, the use of the Internet of Things (IoT) can increase student interest in learning.
\end{abstract}

Keywords:IoT, Natural Science Practicum.

\begin{abstract}
Abstrak
Mata pelajaran IPA, pada beberapa BAB pelajaran yang membutuhkan praktikum. Penerapan ilmu IPA telah banyak dikembangkan sebagai alat demonstrasi saat menjelaskan konsep IPA yang abstrak. Pada dasarnya IPA merupakan pembelajaran yang mendasari segala kegiatan eksperimental. Alat IPA yang dapat digunakan sebagai media pembelajaran digunakan sebagai alat praktikum atau alat peraga demonstrasi untuk materi IPA, instrumentasi di perguruan tinggi serta materi IPA tentang Gerak Lurus di sekolah. keterbaruan pada penelitian ini adalah Pengembangan Alat Praktikum IPA berbasis Internet Of Thigs. Sehingga mampu menumbuh kembangkan minat siswa untuk belajar IPA di tengah pandemik covid-19. keterbaruan pada penelitian ini adalah Pengembangan Alat Praktikum IPA berbasis Internet Of Thigs. Sehingga mampu memberikan alternatif untuk praktikum mata pelajaran IPA secara daring di tengah pandemik covid-19. Penelitian ini menggunakan metode R \& D (Research And Development). Model yang digunakan pada penelitian ini adalah model ADDIE. Sedangkan untuk analisis keterlaksanaan RPP selama proses pembelajaran adalah 3,706 dengan kategori sangat baik. Dari hasil pengamatan 2 orang pengamat bahwa penggunaan IoT sangant membantu siswa dalam memahami konsep GLB di tengah covid 19. Hal ini menunjukkan bahwa selain dapat meningkatkan prestasi belajar siswa, penggunaan Internet of Things (IoT) dapat meningkatkan minat siswa untuk belajar.
\end{abstract}

Kata Kunci: IoT, Praktikum IPA.

\section{PENDAHULUAN}

Pandemi Covid-19 di Indonesia saat ini berdampak bagi seluruh masyarakat. Menurut Kompas, 28/03/2020 dampak virus Covid-19 terjadi diberbagai bidang seperti sosial, ekonomi, pariwisata dan pendidikan. Pada tanggal 24 maret 2020 Menteri Pendidikan dan Kebudayaan Republik Indonesia mengeluarkan Surat Edaran Nomor 4 Tahun 2020 Tentang Pelaksanaan

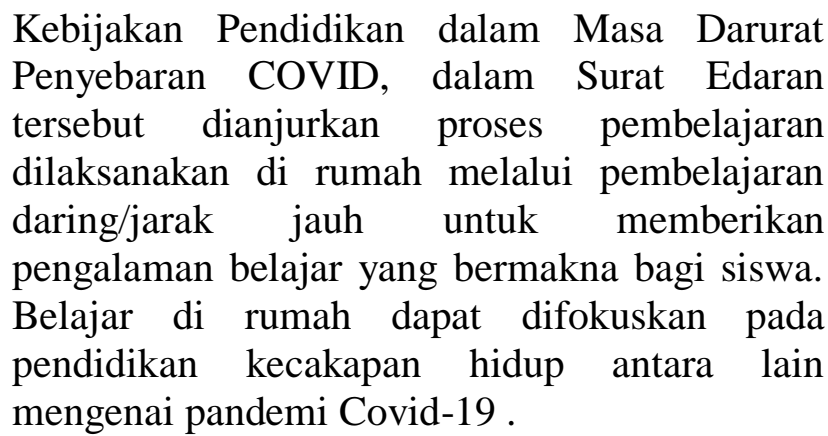

Kebijakan Pendidikan dalam Masa Darurat tersebut dianjurkan proses pembelajaran dilaksanakan di rumah melalui pembelajaran daring/jarak jauh untuk memberikan pengalaman belajar yang bermakna bagi siswa. Belajar di rumah dapat difokuskan pada mengenai pandemi Covid-19 
Pembelajaran daring juga harus dapat berinteraksi di antara mereka untuk memastikan bahwa pendidikan karakter dapat terus berlanjut bahkan dalam lingkungan virtual. "Idealnya solusi pembelajaran daring tidak hanya sebagai literacy center, tetapi juga merupakan platform yang dapat mengakomodir sistem pembelajaran sekolah. Dengan demikian, pembelajaran daring memang dapat dijadikan solusi karena telah digunakan pada Covid-19 atau yang lebih baru (Dewi, 2020).

Khusus pada mata pelajaran IPA, pada beberapa $\mathrm{BAB}$ pelajaran yang membutuhkan praktikum. Penerapan ilmu IPA telah banyak dikembangkan sebagai alat demonstrasi saat menjelaskan konsep IPA yang abstrak. Pada dasarnya IPA merupakan pembelajaran yang mendasari segala kegiatan eksperimental. Alat IPA yang dapat digunakan sebagai media pembelajaran digunakan sebagai alat praktikum atau alat peraga demonstrasi untuk materi IPA, instrumentasi di perguruan tinggi serta materi IPA tentang Gerak Lurus di sekolah. Dalam pemanfaatan alat demonstrasi saat ini kurang memadai. Salah satu materi IPA yang kurang efektif dalam pemanfaatan alat demonstrasi yaitu alat praktikum Gerak Lurus Beraturan (GLB) dan Gerak Lurus Berubah Beraturan (GLBB) berbasis Internet of Things pada mata pelajaran IPA SMA. Pada sub materi praktikum GLB dan GLBB dapat dikembangkan media pembelajaran

berupa alat peraga yang digunakan untuk menjelaskan cara pengambilan data praktikum secara real-time.Pada tanggal 31 Desember 2019 muncul kasus serupa dengan Pneumonia yang tidak diketahui di Wuhan China, (Lee 2020). Kasus tersebut disebabkan oleh virus Corona atau yang dikenal dengan covid-19 (Corona Virus Deivisase 19). Berdasarkan data WHO diperoleh bahwa COVID-19 telah menjadi pandemic global dengan jumlah kasus positif sebesar 41,2 juta, sembuh 28,5 juta dan meninggal 1, 14 juta (update : 24-10-2020). Virus Corona juga telah mewabah di Indonesia sejak bulan Maret 2020 terdapat 381.910 kasus positif, sembuh 305.100 kasus dan meninggal 13.077 kasus dari 34 Provinsi di seluruh Indonesia (Herliandry et al., 2020). Wabah yang melanda dunia bahkan
Indonesia memberikan dampak yang siginifikan baik dari ekonomi bahkan pendidikan. Melalui Kementrian Pendidikan dan Kebudayaan pemerintah telah memberikan komando untuk memberhentikan pembelajaran tatap muka langsung (konvensional) dan memberikan instruksi untuk melaksanakan pembelajaran secara daring (surat edaran) Kemedikbud DIKTI No 1 Tahun 2020) Sekolah maupun perguruan tinggi di seluruh Indonesia.

Pembelajaran daring juga harus dapat berinteraksi antar pendidikan dengan siswa dan siswa dengan siswa agar memastikan bahwa pendidikan karakter tetap berlanjut bahkan dalam lingkungan virtual. Selain itu pula, beberapa aspek penelian untuk peserta didik yang menjadi kendala oleh para pendidik maupun peserta didik. Salah satu dari aspek tersebut adalah penilian psikomotorik peserta didik dan beberapa matapelajaran yang mengharuskan peserta didik untuk melakukan praktikum contoh praktikum GLB dan GLBB pada matapelajaran IPA (Dewi, 2020).

Penelitian tetang Pengembangan Alat Pembelajaran Praktikum IPA untuk SMA berbasis Internet of Thigs (IoT) dimasa pandemi Covid-19 (Herliandry et al., 2020) (Dewi, 2020)(Kurniawati et al., 2015)(Pamungkas \& Sukarman, 2020)(Dewi, 2020)(Bughin et al., 2013) Beberapa penelitian yang sudah peneliti lakukan, seperti Vibration Charcteristics study on observatory using accelerometer ADXL345 sensor and Arduino. Serta Pengembangan Sistem Pemantauan Getaran padaObservatorium UAD berbasis Internet of Things Berdasarkan penelitan yang sudah dilakukan yang telah di uraikan maka keterbaruan pada penelitian ini adalah Pengembangan Alat Praktikum IPA berbasis Internet of Thigs. Sehingga mampu memberikan alternatif untuk praktikum mata pelajaran IPA secara daring di tengah pandemik covid-19.

\section{METODE}

Penelitian ini menggunakan metode $\mathrm{R} \&$ D (Research And Development). Model yang digunakan pada penelitian ini adalah model ADDIE, salah satu model yang ada pada metode R \& D. Model ADDIE memperlihatkan tahapan 
dasar desain system pembelajaran sederhana dan mudah dipelajari. Model ini terdiri dari lima tahapan utama yaitu Analysis, Design, Development,

Implementation, and Evaluation(Bughin et al., 2013).

Prosedur penelitian ini menggunakan model sekuensial linier. Model ini mengusulkan pendekatan pengembangan perangkat lunak secara sekuensial atau terurut dimulai dari analisis, desain, pengodean, pengujian dan pendukung. Pada gambar 1 digambarkan sebagai skema model sekuensial linier.

Alur penelitian sebaiknya disajikan di bagian ini dilengkapi dengan keterangan gambar. Keterangan gambar diletakkan menjadi bagian dari judul gambar (figure caption) bukan menjadi bagian dari gambar. Metode-metode yang digunakan dalam penyelesaian penelitian dituliskan di bagian ini.

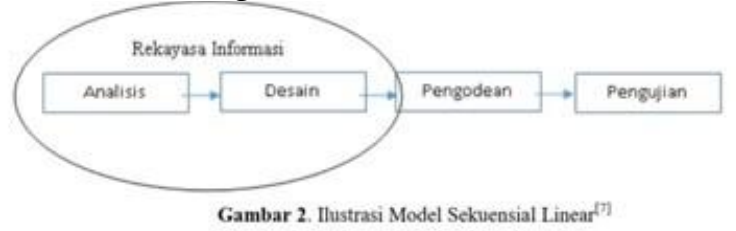

Model sekuensial linier ini juga pernah dilakukan oleh Viana dan Laila tahun 2019 dengan rancangan bangun sistem informasi sekolah berbasis website, pada SMA Rimba Madya Bogor (Purnama et al., 2014). Hal yang sama dilakukan oleh Achmad Rifai dan Yasinta Prabawati Yuniar melakukan penelitian tentang pembuatan sistem informasi ujian berbasis web menggunakan

metode waterfall yang terdiri dari analisis, desain, pengkodean dan pengujian serta entity relationship diagram dalam merancang database (Rifai \& Yuniar, 2019).

\section{HASIL DAN PEMBAHASAN}

Penelitian ini dilakukan dengan
mengubah kemiringan bidang untuk memperoleh percepatan kereta. Data diambil dengan menggunakan sensor ultrasonik (HCSR04) berbasis IoT dengan menggunakan web server lokal (Dewi, 2020). Pada web tersebut data ditampilkan dengan grafik dan dapat disimpan dengan format excel[2]. Hasil pembacaan data menggunakan sensor HC-SR04 dapat ditunjukkan pada gambar 1 .

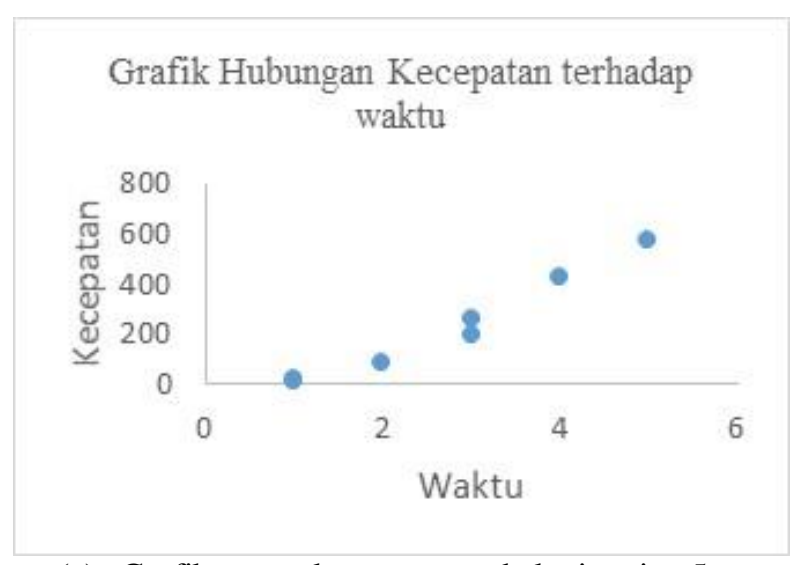

(a) Grafik antara kecepatan pada ketinggian $5 \mathrm{~cm}$

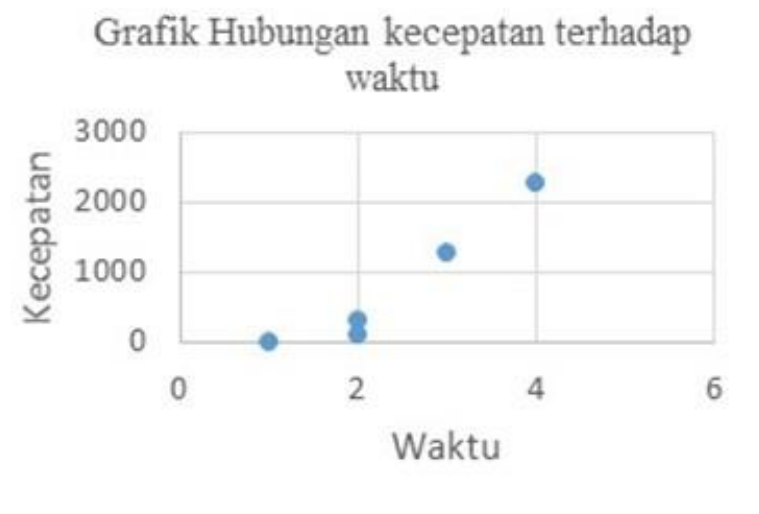

(b) Grafik antara kecepatan pada ketinggiang $11 \mathrm{~cm}$. Data diambil dengan menggunakan sensor ultrasonik (HC-SR04) berbasis IoT dengan menggunakan web server lokal. Pada web tersebut data ditampilkan dengan grafik dan dapat disimpan dengan format excel. Hasil pembacaan data menggunakan sensor HC-SR04 dapat ditunjukkan pada gambar 1 dari grafik hubungan yang ditunjukkan pada gambar 1 . Bahwa semakin tinggi bidang miring maka semakin besar percepatan kereta. Sesuai dengan tujuan praktikum, membentuk grafik hubungan waktu terhadap kecepatan, selanjutnya hasil keterlaksanaan RPP dapat dilihat pada grafik dibawah ini :

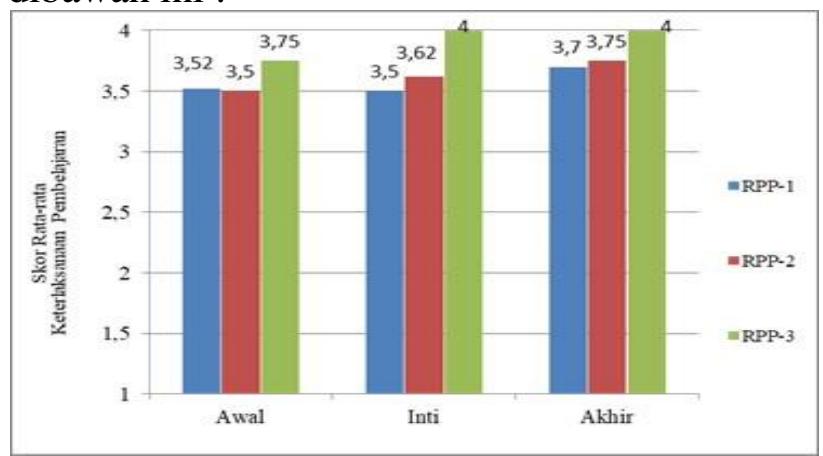


Keterlaksanaan perangkat pembelajaran diamati oleh dua orangpengamat. Pengamatan dilakukan selama 3 kali pertemuan yang merupakan implementasi dari RPP 1, RPP 2, dan RPP 3. Hasil analisis data pengamatan dan kecocokan dari dua pengamat mengenai keterlaksanaan Rencana Pelaksanaan Pembelajaran (RPP) dapat dilihat pada Gambar 1. rata-rata skor keterlaksanaannya pada RPP 1 adalah 3,59 dengan kategori sangat baik, RPP 2 adalah 3,62 dengan kategori sangat baik dan RPP 3 adalah 3,91 dengan kategori sangat baik, sehingga skor rata-rata keterlaksanaan keseluruhan kegiatan pembelajaran adalah 3,706 dengan kategori Sangat Baik.

Percobaan yang telah diterapkan dalam penelitian ini merupakan pemanfaatan Internet of Things (IoT). IoT adalah sebuah konsep/skenario dimana suatu objek yang memiliki kemampuan untuk mentransfer data melalui jaringan tanpa memerlukan interaksi manusia ke manusia atau manusia ke komputer. IoT telah berkembang dari konvergensi teknologi nirkabel, micro electro mechanical systems (MEMS), dan Internet (Serway \& Kirkpatrick, 1988). Pada dasarnya IPA merupakan pembelajaran yang mendasari segala kegiatan eksperimental. Alat IPA yang digunakan sebagai media pembelajaran. Salah satu materi IPA yang kurang efektif dalam pemanfaatan alat demonstrasi yaitu alat praktikum Gerak Lurus Beraturan (GLB) dan Gerak Lurus Berubah Beraturan (GLBB) berbasis Internet of Things pada mata pelajaran IPA SMA(Bughin et al., 2013). Pada sub materi praktikum GLB dan GLBB dapat dikembangkan media pembelajaran berupa alat peraga yang digunakan untuk menjelaskan cara pengambilan data praktikum secara real-time. Dari hasil pengamatan 2 orang pengamat bahwa pemanfaatan IoT sangant membantu siswa dalam memahami konsep GLB di tengah covid 19. Selain itu siswa mampu memanfaatkan teknologi sebagai media pembelajaran yang dapat digunakan oleh siswa dimana dan kapanpun (Bughin et al., 2013).

Persentase respon siswa terhadap model pembelajaran IPA menggunakan Internet of Things (IoT) sebesar 90\% yang termasuk dalam kategori sangat baik berdasarkan pedoman konversi skala 5. Hal ini menunjukkan bahwa selain dapat meningkatkan prestasi belajar siswa, pemanfaatan Internet of Things (IoT) dapat meningkatkan minat siswa untuk belajar.

\section{KESIMPULAN}

Berdasarkan hasil belajar dan hasil respon siswa maka, pemanfaatan Internet of Things (IoT) untuk praktikum ipa pada materi gerak lurus berubah beraturan (glbb) dalam pembelajaran daring selama pandemi covid-19 dapat disimpulkan bahwa Internet of Things (IoT) dapat digunakan sebagai alternatif untuk praktikum IPA dalam pembelajaran daring.

\section{SARAN}

Adapun saran dalam penelitian selanjutnya adalah bisa lebih inovatif lagi dalam memanfaatkan IoT dalam pembelajaran IPA dengan menggunakan materi lainnya.

\section{UCAPAN TERIMA KASIH}

Terima kasih Tim peneliti ucapkan kepada KEMENRISTEK DIKTI BRIN yang telah mempercayakan penelitian ini dengan nomor kontrak :069/E4.1/AK.04.PT/2021 Indonesia yang telah membantu mendanai penelitian ini $100 \%$. Ketua STKIP Harapan Bima dan semua pihak yang telah membantu dalam proses penelitian ini yang tidak dapat disebutkan satu per satu.

\section{DAFTAR PUSTAKA}

Bughin, J., Chui, M., \& Manyika, J. (2013). Ten IT-enabled business trends for the decade ahead. McKinsey Quarterly.

Dewi, W. A. F. (2020). Dampak COVID-19 terhadap Implementasi Pembelajaran Daring di Sekolah Dasar. EDUKATIF : JURNAL ILMU PENDIDIKAN. https://doi.org/10.31004/edukatif.v2i1. 89

Herliandry, L. D., Nurhasanah, N., Suban, M. E., \& Kuswanto, H. (2020). Pembelajaran Pada Masa Pandemi Covid-19. JTP - Jurnal Teknologi Pendidikan. https://doi.org/10.21009/jtp.v22i1.1528 6

Kurniawati, L., Akbar, R. O., \& Ali misri, M. 
(2015). PENGARUH PENERAPAN

METODE PEMBELAJARAN

PRAKTIKUM TERHADAP

KETERAMPILAN BERPIKIR

KRITIS MATEMATIKA SISWA

KELAS VIII SMP N 3 SUMBER

KABUPATEN CIREBON. Eduma:

Mathematics Education Learning and

Teaching.

https://doi.org/10.24235/eduma.v4i2.30

Pamungkas, D. E., \& Sukarman, S. (2020).

TRANSFORMASI DUNIA

PENDIDIKAN DI SEKOLAH

DASAR DALAM MASA PANDEMI

COVID-19. Jurnal Review Pendidikan

Dasar ....

Purnama, J., Ernawati, \& Erlansari, Aan, S. (2014). Rancang Bangun Aplikasi Layanan Berbasis Lokasi Dengan Penerapan Augmented Reality Menggunakan Metode Markerless Berbasis Android (Studi Kasus: Pencarian Perangkat Daerah Kota Bengkulu). Jurnal Rekursif.

Rifai, A., \& Yuniar, Y. P. (2019). Penerapan Metode Waterfall Dalam Perancangan Sistem Informasi Ujian Pada SMK Indonesia Global Berbasis Web. Jurnal Khatulistiwa Informatika. https://doi.org/10.31294/jki.v7i1.5736

Serway, R. A., \& Kirkpatrick, L. D. (1988). Physics for Scientists and Engineers with Modern Physics. The Physics Teacher.

https://doi.org/10.1119/1.2342517 